\title{
Predicting growth of Listeria monocytogenes in fresh ricotta
}

Tirloni, Erica; Stella, Simone; Bernardi, Cristian; Dalgaard, Paw; Rosshaug, Per Sand

\section{Published in:}

Food Microbiology

Link to article, DOI:

10.1016/j.fm.2018.10.004

Publication date:

2019

Document Version

Peer reviewed version

Link back to DTU Orbit

Citation (APA):

Tirloni, E., Stella, S., Bernardi, C., Dalgaard, P., \& Rosshaug, P. S. (2019). Predicting growth of Listeria monocytogenes in fresh ricotta. Food Microbiology, 78, 123-133. https://doi.org/10.1016/j.fm.2018.10.004

\section{General rights}

Copyright and moral rights for the publications made accessible in the public portal are retained by the authors and/or other copyright owners and it is a condition of accessing publications that users recognise and abide by the legal requirements associated with these rights.

- Users may download and print one copy of any publication from the public portal for the purpose of private study or research.

- You may not further distribute the material or use it for any profit-making activity or commercial gain

- You may freely distribute the URL identifying the publication in the public portal 


\section{Accepted Manuscript}

Predicting growth of Listeria monocytogenes in fresh ricotta

Erica Tirloni, Simone Stella, Cristian Bernardi, Paw Dalgaard, Per Sand Rosshaug

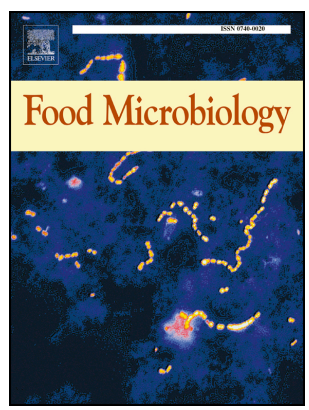

PII:

S0740-0020(18)30481-7

DOI:

10.1016/j.fm.2018.10.004

Reference: $\quad$ YFMIC 3094

To appear in: Food Microbiology

Received Date: 27 May 2018

Revised Date: 16 October 2018

Accepted Date: 17 October 2018

Please cite this article as: Tirloni, E., Stella, S., Bernardi, C., Dalgaard, P., Rosshaug, P.S., Predicting growth of Listeria monocytogenes in fresh ricotta, Food Microbiology (2018), doi: https://doi.org/10.1016/ j.fm.2018.10.004.

This is a PDF file of an unedited manuscript that has been accepted for publication. As a service to our customers we are providing this early version of the manuscript. The manuscript will undergo copyediting, typesetting, and review of the resulting proof before it is published in its final form. Please note that during the production process errors may be discovered which could affect the content, and all legal disclaimers that apply to the journal pertain. 


\section{Predicting growth of Listeria monocytogenes in fresh ricotta}

2

3 Erica Tirloni ${ }^{1 *}$, Simone Stella ${ }^{1}$, Cristian Bernardi ${ }^{1}$, Paw Dalgaard ${ }^{2}$, Per Sand Rosshaug ${ }^{2}$

4

5

$6 \quad{ }^{1}$ Department of Health, Animal Science and Food Safety, University of Milan, Milan, Italy

$7{ }^{2}$ Technical University of Denmark, National Food Institute (DTU Food), Kemitorvet, building 202, 2800, Kgs.

8 Lyngby, Denmark

9

10 *Corresponding author. Department of Health, Animal Science and Food Safety, University of Milan, Via Celoria 10, 1120133 Milan, Italy. Tel: +390250317855; E-mail address: erica.tirloni@ unimi.it (E. Tirloni).

12

13 


\section{Abstract}

Challenge tests with eight brands of fresh ricotta showed rapid growth of Listeria monocytogenes and significant variability in physical-chemical characteristics. Thus, two cardinal parameters models were developed for the growth of L. monocytogenes in ricotta including, respectively, terms for temperature (Model 1) and temperature and $\mathrm{pH}$ (Model 2). Also an extensive, existing growth model including the effect of organic acids (Model 3) was product recalibrated to predict growth of L. monocytogenes in ricotta. Interestingly, a lack of anti-listerial effect of organic acids in ricotta was observed in this study. The range of applicability of Models 1 and 2 in ricotta (characterized by absence of competitive microbiota) included storage at temperatures from 4.1 to $20.6^{\circ} \mathrm{C}, \mathrm{pH}$ from 5.5 to 6.6 , moisture contents from $72 \%$ to $82 \%, \mathrm{NaCl}$ from $0.38 \%$ to $0.60 \%$, concentrations of acetic acid from 579 to $1,559 \mathrm{ppm}$ in the water phase, citric acid from 14,774 to $46,116 \mathrm{ppm}$ in the water phase, and lactic acid from 0 to $4,146 \mathrm{ppm}$ in the water phase. Comparing observed and predicted maximum specific growth rates of $L$. monocytogenes in ricotta showed a bias-factor significantly above 1 , for existing models developed for broth and these models were thus fail-safe with predicted growth being faster than observed, while typically below 1 for models developed for other food types. The models developed in the present study showed bias-factors of 1.10, 1.06 and 0.78 , respectively, for Model 1, 2, and 3. In particular, Model 1 and 2 developed and successfully validated could allow an easy determination of safe shelf-life of ricotta and facilitated the reformulation the product with the aim to increase shelf-life or safety. 
Fresh ricotta is an unripened acid-heat coagulated dairy product originating from Italy. It is an important fresh dairy product in the Italian market and it is also popular internationally (Assolatte, 2014). This product is mainly consumed as it is, without a heat treatment and it can be used for cakes and sweets as well as an ingredient in main courses like pasta.

Ricotta is mainly produced from bovine whey resulting from the production of different cheeses such as mozzarella. Protocols for the manufacture of ricotta varies. In industrial production, the whey is typically acidified by citric acid, and then heated to $65-70{ }^{\circ} \mathrm{C}$. Whole milk and/or skim milk are usually added (5-25\% v/v) and milk cream $(\sim 1 \%)$ can be added at temperatures of $75-80^{\circ} \mathrm{C}$. Then, $\mathrm{NaCl}(0.5 \% \mathrm{w} / \mathrm{v})$ is supplemented and heating continues to $85-$ $95{ }^{\circ} \mathrm{C}$. Food-grade organic acids (mainly acetic, citric and lactic acids) are used at this stage to reduce the $\mathrm{pH}$, usually to around 6.0, in order to coagulate the whey proteins. Later, the product is typically hot filled/packaged in basket moulds under vacuum, gas flushed, and finally sealed at high temperatures of $75^{\circ} \mathrm{C}$ (Farkye, 2004; Mucchetti and Neviani, 2006). The chilled shelf life of industrial fresh ricotta is typically $20-40$ days.

The physical-chemical characteristics of ricotta including high moisture content, low salt content and a relatively high $\mathrm{pH}$ value (6.0-6.5), has previously been reported to support the growth of the pathogenic bacterium $L$. monocytogenes (Genigeorgis et al., 1991). This is important as Italian and international scientific studies found $L$. monocytogenes in fresh and soft dairy products made from raw, thermized and pasteurized milk (De Buyser et al., 2001; Little et al., 2008; Lundén et al., 2004; Martinez-Rios and Dalgaard, 2018). Also for ricotta-type products the presence of this pathogen has been sporadically reported (RASFF, 2015). Due to the processing including heating to $85-95^{\circ} \mathrm{C}$ the presence of L. monocytogenes in ricotta is most likely caused by post-heating contamination. However, there have been identified outbreaks of listeriosis associated with the consumption of fresh cheese and the predominant microorganisms responsible include Listeria monocytogenes (Zottola and Smith, 1991; Oliver et al., 2005; Little et al., 2008, MartinezRios and Dalgaard, 2018).

The EU Regulation no. 2073/2005, and subsequent amendments, sets food safety criteria for L. monocytogenes in ready-to-eat (RTE) food. Before the food has left the immediate control of the food manufacturer, the microorganism must be absent in $5 \times 25 \mathrm{~g}$, while, at the point of consumption, it must not exceed $100 \mathrm{CFU} \mathrm{g}^{-1}$. Based on the chemicalphysical characteristics of ricotta, in particular $\mathrm{pH}$ and water activity, the EU-regulation also categorizes this product as a ready-to-eat food able to support the growth of L. monocytogenes. Moreover the EU-regulation recognizes and points at predictive modelling as a method to document safety of RTE foods. 
Mathematical predictive models, quantifying microbial responses to physical-chemical characteristics of fresh ricotta, could be used to predict potential growth at intended and at abusive storage conditions and thereby facilitate the determination of safe product shelf-life. Furthermore, a validated model can be used to predict a product reformulation (e.g. changed $\mathrm{pH}$ and concentration of organic acids) that inhibit or prevent growth of L. monocytogenes as previously shown for other food commodities such as seafood (Mejlholm and Dalgaard, 2009, 2015).

Several mathematical modelling approaches have been proposed to predict microbial growth in food products. Cardinal parameter models are popular due to their parameters with an apparent biological meaning and extensive cardinal parameter models, including the effect of various inhibitory components have previously been developed for $L$. monocytogenes (Augustin and Carlier, 2000 a,b; Augustin et al., 2005; Coroller et al., 2012; Mejlholm and Dalgaard, 2009). Validated models that specifically predict growth of L. monocytogenes in fresh ricotta are not available, but as mentioned above they could be useful to set formulations and storage conditions leading to L. monocytogenes inhibition.

The aim of the present study was to identify or develop and validate predictive models to accurately predict the potential growth of L. monocytogenes in fresh ricotta. Firstly, a physical-chemical and microbiological characterization of fresh ricotta from eight major Italian producers was performed. Secondly, challenge tests with L. monocytogenes in the eight brands of fresh ricotta at different static and dynamic storage temperatures were conducted including also challenge tests with modified concentrations of organic acids. Finally, the collected information and data were used to (i) either develop or calibrate selected models to growth rates in fresh ricotta and (ii) to evaluate the performances of existing or new predictive models for ricotta.

2

2.1 .

\section{Materials and methods}

Microbiological screening of fresh ricotta

Fresh ricotta samples from eight different producers $(\mathrm{A}-\mathrm{H})$ were obtained on the day of production. The weight of the samples varied from 100 to $450 \mathrm{~g}$, depending on the producer and the declared commercial shelf-life was 20-40 days at $4^{\circ} \mathrm{C}$ and under aerobic conditions (residual oxygen was determined as $18.84 \pm 1.21 \%$ by using a Dansensor gas analyser). During transport, samples were kept in ice and at the laboratory they were stored at $4{ }^{\circ} \mathrm{C}$ and analysed within 24 hours. Microbiological analyses were carried out at three different storage times: beginning (T0), middle (T1) and end of the shelf-life of 20-40 days as indicated by the producers (T2). All analyses were performed at least in triplicate. 
For microbial counts, $10 \mathrm{~g}$ of each sample were homogenized in $90 \mathrm{ml}$ of pre-chilled sterile diluent solution $(0.85 \% \mathrm{NaCl}$ and $0.1 \%$ peptone), for $60 \mathrm{~s}$ in a Stomacher 400 (Seward Medical, London, UK) and serial 10-fold dilutions were prepared. Total Viable Count (TVC) was determined using spread plating on Plate Count Agar (Oxoid, Basingstoke, UK, CM0325) according to the ISO 4833:2013 method. Lactic acid bacteria (LAB) were enumerated on de Man-Rogosa-Sharpe agar (Oxoid, CM0361), at $\mathrm{pH} 5.5$; plates were incubated at $30^{\circ} \mathrm{C}$ for $48 \mathrm{~h}$ under anaerobic conditions (AnaeroGen, Oxoid, AN0025). Qualitative detection of L. monocytogenes in $25 \mathrm{~g}$ of ricotta was performed according to the AFNOR BRD 07/4-09/98 method, including enrichment in Half fraser broth followed by plating onto ALOA agar.

\section{Challenge tests with inoculated fresh ricotta}

A series of challenge tests was carried out with the purpose of establishing data to calibrate and validate growth models of L. monocytogenes in ricotta. Growth of L. monocytogenes in eight different brands of ricotta was determined in 18 challenge tests with 13 at constant storage temperatures and five at dynamic temperatures (Table 1). Seven challenge tests used for model calibration were performed at 4.1-20.6 ${ }^{\circ} \mathrm{C}$ using different brands of ricotta with varying $\mathrm{pH}$ and concentrations of organic acids (See 2.2.1). Model calibration means finding the best model curve through observations by adjusting model parameter values so that model predictions conform to observed data as well as possible. It is here done by minimizing sums of squares of residuals (see details in 2.3.2). Validation data from eleven challenge tests were used to evaluate the performance of the novel predictive model for ricotta and of these, six were performed at constant temperature and five were performed at dynamic temperatures (Table 1). However, all 13 data sets conducted at static temperature were used to validate existing models ability to predict growth rates, because these models were not derived from the calibration data in this study. The five challenge tests conducted at dynamic temperature were used to evaluate how the models predicted bacterial growth over time during dynamic temperature conditions. The challenge tests included treatments with organic acids added to ricotta in the laboratory (Table 1). All microbiological analyses were performed in triplicate. Thus, the effect of temperature (4.1-20.6 $\left.{ }^{\circ} \mathrm{C}\right), \mathrm{pH}(5.49-6.61)$ and organic acids concentrations on microbial growth was reflected in the calibration data sets (Table 1; Table 2). In three series of challenge tests organic acids were added to the brand of ricotta characterized by lower organic acids concentration $(\mathrm{G})$ to observe more clearly the responses of L. monocytogenes to acetic, citric, and lactic acids in ricotta (see Table 1; data set \# 19-27 and section 2.2.4).

2.2.1 Physical-chemical characterization 

were determined. Concentrations of organic acids were determined by HPLC (Tormo and Izco, 2004). Briefly, $1.0 \mathrm{~g}$ of fresh ricotta was diluted to $5.0 \mathrm{ml}$ in water and vigorously shaken by using a vortex during $20 \mathrm{~s}$. After centrifugation (3000 x g; 15 min.) the supernatant was filtered through a $0.45 \mu \mathrm{m}$ cellulose membrane. The HPLC system consisted of two pumps (Waters 510, Milan, Italy), an auto-sampler (Waters 717 plus) and a UV-VIS detector (Waters 484) set at $210 \mathrm{~nm}$. The separation was performed on a Rezex ROA column $300 \mathrm{~mm}$ x $7.8 \mathrm{~mm}, 8 \mu \mathrm{m}$ (Phenomenex, Torrance, USA). The mobile phase $\left(0.5 \mathrm{ml} \mathrm{min}^{-1}\right.$ in isocratic mode) was $0.005 \mathrm{~N}$ sulphuric acid. External standards were used for identification and quantification of acetic, citric and lactic acids. The limit of detection (LOD: 0.076, 0.23 and $0.24 \mathrm{mM}$ for acetic, citric and lactic acid respectively) and limit of quantification (LOQ: 0.39, 0.43 and $0.77 \mathrm{mM}$ for acetic, lactic and citric acid respectively) were determined. LOD and LOQ were calculated by the signal-to- noise approach (ICH, 1995).

Ricotta samples used for challenge tests were inoculated with a three strains cocktail of L. monocytogenes including a human isolate (ATCC 7644), an isolate from a fresh dairy product (strain MS12209), provided by DTU Food and a strain previously involved in a dairy associated outbreak (LM 6), supplied by Arla Strategic Innovation Center (ASIC, Stockholm, Sweden). The strain stocks were kept frozen at $-80^{\circ} \mathrm{C}$ in Microbank Cryogenic vials (ProLab Diagnostics U.K., Merseyside, UK). From each stock culture, a loop was transferred to Brain Heart Infusion broth (BHI) (Oxoid, CM1135) with $\mathrm{pH} 7.2$ and incubated at $37^{\circ} \mathrm{C}$ for $24 \mathrm{~h}$. In order to pre-adapt the cells to the environmental conditions of each of the challenge tests, cultures were subsequently re-inoculated in BHI broth with a $\mathrm{pH}$ around 6 (adjusted with $\mathrm{HCl}$ ) according to the characteristics of the product to be inoculated and then incubated at different temperatures $\left(4,8,12,20^{\circ} \mathrm{C}\right)$ depending on the storage temperature of the challenge test (Table 1$)$. The cultures were harvested in late exponential growth phase, defined as a relative change in absorbance of 0.05-0.2 at $540 \mathrm{~nm}$ (Jenway 6105, Staffordshire, UK). Cell concentrations of these pre-cultures were determined by microscopy at 1000x magnification (Motic, B310, Wetzlar, Germany), considering that one cell per field of view corresponded to a concentration around $10^{6} \mathrm{CFU} \mathrm{ml}^{-1}$ (Adam and Moss, 2000). Finally, pre-cultures of individual isolates were diluted in sterile saline water $(0.85 \% \mathrm{NaCl})$ to obtain the same concentrations and mixed together in equal volumes (Mix-Lm). The Mix-Lm culture was diluted with sterile saline in order to reach an initial concentration of 3-4 $\log \mathrm{CFU} \mathrm{g}^{-1}$ after 
inoculation of the product. To minimize changes in product characteristics, the inoculum volume did not exceed $1 \%$ of the weight of fresh ricotta samples. Thus, the inoculum was between 1 and $4.5 \mathrm{~mL}$ depending on the total volume of ricotta (from 100 to $450 \mathrm{~g}$ ). The inoculated samples were then incubated at selected temperature conditions (Table 1).

\subsubsection{Microbial sampling}

Inoculated fresh ricotta samples were periodically analysed and L. monocytogenes counts were determined in triplicate during the storage period of challenge tests. Each challenge test included from 8 to 29 times of repeated samplings. At each sampling time, $10 \mathrm{~g}$ of ricotta were 10 -fold diluted in pre-chilled sterile saline $(0.85 \% \mathrm{NaCl}$ and $0.1 \%$ peptone) and homogenized for $60 \mathrm{~s}$ in a Stomacher 400 (Seward Medical, London, UK). Further appropriate 10fold dilutions of the homogenates were made with pre-chilled sterile saline. L. monocytogenes was enumerated by spread plating on Palcam Agar (Oxoid, CM0877) added Palcam Selective Supplement (Oxoid, SR0150) and incubated at $37^{\circ} \mathrm{C}$ for $48 \mathrm{~h}$.

During storage of ricotta, temperature was regularly recorded by data loggers (Escort iLog, Escort Data Logging System Ltd, Aesch Bei Birmensdorf, $\mathrm{CH}$ ) and $\mathrm{pH}$ was measured at each sampling time in triplicate by using a $\mathrm{pH}$ meter (Amel Instruments, Milan, I) (See 2.2.1).

\subsubsection{Effect of organic acids}

Specific challenge tests with ricotta were carried out to establish the range of Minimum Inhibiting Concentrations (MIC) for undissociated acetic, citric, and lactic acids on L. monocytogenes. Ricotta samples from the brand showing the lowest organic acids concentrations (as described in section 2.2.1) were obtained. Considering the organic acids present in ricotta and resulting from industrial processing, nine treatments with different contents of organic acids were generated by adding three different quantities for each of the three food grade organic acids (Table 1; data set \# 19-27). The resulting total concentrations of organic acids for samples of the nine treatments were estimated with the HPLC method described in section 2.2.1. Each of the three organic acid was added to obtain a final concentrations for acetic acid (code 1005706, Sigma Aldricht, Steinheim, Germany) of 37.03 mM, $74.96 \mathrm{mM}$ and 173.1 $\mathrm{mM}$, for lactic acid (code 252476, Sigma Aldricht) of $35.25 \mathrm{mM}, 111.0 \mathrm{mM}$ and $213.7 \mathrm{mM}$, and for citric acid (code 251275, Sigma Aldricht) of $1764 \mathrm{mM}, 2803 \mathrm{mM}$ and $3915 \mathrm{mM}$. The $\mathrm{pH}$ was adjusted to a level of 5.0-5.1 with $\mathrm{HCl} /$ 
$171 \mathrm{NaOH}$, in order to obtain high undissociated amount of organic acid. The undissociated concentrations of organic acids 172 in the nine ricotta challenge tests were estimated with Equation (1):

173

175

176

177

178

179

180

181

182

183

184

185

$$
\text { Undissociated organic acid }(m M)=\frac{\text { organic acid }(m M)}{1+10^{(p H-p K a)}}
$$

The applied pKa values were 4.76, 3.13, and 3.86 for acetic acid, citric acid, and lactic acid, respectively. The highest concentrations of undissociated acid reached were $68.4 \mathrm{mM}$ for acetic acid, $42.5 \mathrm{mM}$ for citric acid, and $14.7 \mathrm{mM}$ for lactic acid. All the samples were then inoculated with L. monocytogenes (approximately 3-4 $\log \mathrm{CFU} \mathrm{g}{ }^{-1}$ ) (see section 2.2.2) and bacterial enumeration was immediately performed in triplicate as described in section 2.2.3. The samples were then incubated at $15.2^{\circ} \mathrm{C}$ during 7 days and then L. monocytogenes was enumerated again in triplicate. An increase of $+0.5 \mathrm{Log} \mathrm{CFU} \mathrm{\textrm {g } ^ { - 1 }}$ was used to discriminate growth and no growth in the product. $\mathrm{pH}$ and organic acids concentrations were measured at the beginning and at the end of the trial (see section 2.2.1).

$2.3 \quad$ Modelling

2.3.1 Estimation of kinetic parameters from challenge tests by primary modelling

The initial cell concentration $\left(\log N_{0}, \log \mathrm{CFU} \mathrm{g} \mathrm{g}^{-1}\right)$, lag time $(\lambda, \mathrm{h})$, maximum specific growth rate $\left(\mu_{\max }, \mathrm{h}^{-1}\right)$ and maximum population density $\left(\log N_{\max }, \log \mathrm{CFU} \mathrm{\textrm {g } ^ { - 1 }}\right)$ of L. monocytogenes were determined by fitting a primary model to growth kinetics obtained in each challenge test (Table 1). The Baranyi and Roberts (1994) model was fitted to the log transformed growth data of L. monocytogenes $\left(\log \mathrm{CFU} \mathrm{g}{ }^{-1}\right.$ ) by using the Excel Add-in DMFit of IFR (Institute of Food Research, Reading, UK). A conversion factor of ln 10 was multiplied with the DMfit estimated growth rates, as the bacterial concentrations applied in DMfit were log transformed. Kinetic parameters were estimated for 13 challenge tests conducted at constant temperatures in the present study (Table 1, data set \# 1 to 13).

2.3.2.

Development and calibration of secondary growth rate models for L. monocytogenes in ricotta

Two secondary gamma concept $\mu_{\max }$-models were developed based on seven experimentally obtained $\mu_{\max }-$ values for growth of L. monocytogenes in fresh ricotta (see 2.2). A simple Ratkowsky-type temperature model (Model 1) was fitted to $\mu_{\max }$ values from the calibration challenge tests (Table 1; Equation (2)).

$$
\mu_{\text {max }}=\mu_{\text {ref } 1} \cdot\left(\frac{T-T_{\min }}{T_{\text {ref }}-T_{\min }}\right)^{2}
$$


where $T$ is the storage temperature $\left({ }^{\circ} \mathrm{C}\right), T_{\min }\left({ }^{\circ} \mathrm{C}\right)$ the theoretical minimum temperature for growth of $L$. monocytogenes, $T_{r e f}\left({ }^{\circ} \mathrm{C}\right)$ the reference temperature of $25^{\circ} \mathrm{C}$ and $\mu_{r e f} 1$ the maximum specific growth rate at $T_{r e f}$ Equation (2) was fitted to data sets \#1-7 in order to determine the $\mu_{r e f}$ 1 $^{-}$and $T_{m i n}$-values by using the Add-in Solver of Microsoft Excel to minimize a measure for goodness-of-fit: root mean square error (RMSE).

Secondly, a temperature and $\mathrm{pH}$ model (Presser et al., 1997) with interaction between the two environmental parameters ( $\xi$; Le Marc et al. , 2002) was used (Model 2; Equation (3))

$$
\mu_{\max }=\mu_{\text {ref } 2} \cdot\left(\frac{T-T_{\min }}{T_{r e f}-T_{\min }}\right)^{2} \cdot\left(1-10^{\left(p H_{\min }-p H\right)}\right) \cdot \xi
$$

where $p H_{\min }$ is the theoretical minimum $\mathrm{pH}$ for growth of L. monocytogenes. Equation (3) was fitted as above to determine $\mu_{\text {ref } 2}-$ and $p H_{\text {min }}$-values.

The $T_{\min }$ value fitted in equation (2) was reused directly in equation (3).

Finally, the existing and extensive L. monocytogenes $\mu_{\max }$-model of Mejlholm and Dalgaard (2009) was calibrated by fitting its $\mu_{\text {ref } 3}$ parameter-value as reported for Model 1 above (Model 3; Equation(4)). Importantly, all other parameter values in the Mejlholm and Dalgaard (2009) model were kept unchanged when the $\mu_{\text {ref }}$-value was calibrated.

$$
\begin{aligned}
\mu_{\text {max }}= & \mu_{\text {ref } 3} \cdot\left(\frac{T+2.83}{T_{\text {ref }}+2.83}\right)^{2} \cdot \frac{a_{w}-0.923}{1-0.923} \cdot\left(1-10^{(4.97-p H)}\right) \\
& \left.\cdot\left(1-\frac{L A C_{U}}{3.79}\right) \cdot \frac{32.0-P}{32.0} \cdot\left(\frac{350-N I T}{350}\right)^{2}\right) \\
& \cdot \frac{3,140-C O_{2 \text { equilibrium }}}{3,140} \cdot\left(1-\sqrt{\frac{D A C_{U}}{4.8}}\right) \\
& \cdot\left(1-\sqrt{\frac{A A C_{U}}{M I C_{U} \text { acetic acid }}}\right) \cdot\left(1-\frac{\text { BAC }}{M I C_{U} \text { benzoic acid }}\right) \\
& \cdot\left(1-\frac{\text { CAC } U}{M I C_{U} \text { citric acid }}\right) \cdot\left(1-\frac{\text { SAC } U}{M I C_{U} \text { sorbic acid }}\right) \cdot \xi
\end{aligned}
$$

where $\mu_{\text {ref } 3}$ is equal to $\mu_{\max }$ at the reference temperature $\left(T_{r e f}\right)$ of $25{ }^{\circ} \mathrm{C}$; $\mathrm{T}$ is the temperature (degrees Celsius); $\mathrm{a}_{\mathrm{w}}$ the water activity calculated from the concentration of $\mathrm{NaCl}$ in the water phase of the product; $\mathrm{P}$ and NIT are the concentrations (ppm) of smoke components (phenol) and nitrite, respectively; $\mathrm{CO}_{2}$ equilibrium is the concentration (ppm) of dissolved $\mathrm{CO}_{2}$ at equilibrium; [ $\left.\mathrm{LAC}_{\mathrm{U}}\right],\left[\mathrm{DAC}_{\mathrm{U}}\right],\left[\mathrm{AAC}_{\mathrm{U}}\right],\left[\mathrm{BAC}_{\mathrm{U}}\right],\left[\mathrm{CAC}_{\mathrm{U}}\right]$, and $[\mathrm{SAC} \mathrm{U}$ are the concentrations (mM) of undissociated lactic acid, diacetate, acetic acid, benzoic acid, citric acid, and sorbic acid, respectively; and $\left[\mathrm{MIC}_{\mathrm{U}}\right.$ acetic acid], $\left[\mathrm{MIC}_{\mathrm{U}}\right.$ benzoic acid], $\left[\mathrm{MIC}_{\mathrm{U}}\right.$ citric acid], and $[\mathrm{MIC}$ sorbic acid] are the fitted MICs (mM) of undissociated acetic, benzoic, citric, and sorbic acids, respectively, that prevent growth of $L$. 
monocytogenes. The interaction between environmental parameters $(\xi)$ was modeled as previously described using the Le Marc approach (Le Marc et al. , 2002 ).

For fitting of Model 1, 2 and 3 seven data sets for calibration including six brands of ricotta were used (Table 1; data set \# 1-7).

\subsubsection{Prediction of L. monocytogenes growth in ricotta over time}

The differential form of the Baranyi and Roberts (1994) primary growth model was applied in combination with growth rate models to predict growth of L. monocytogenes over time. Studied growth rate models were equation (2), equation (3), Model 3 and the Augustin et al. (2005) model for liquid dairy products (see section 2.3.4).

The Runge-Kutta $4^{\text {th }}$ order numerical method (Press et al., 2007) was used for numerical integration of the Baranyi and Roberts (1994) model to predict growth over time under both constant and dynamic temperature storage. The time step in the simulations was set to a fixed value of $600 \mathrm{~s}$ and the calculations were conducted in Microsoft Excel. For simplicity the so called adjustment function $\alpha(t)$ of the Baranyi and Roberts (1994) model was set to 1 in case the challenge tests as expected showed no significant lag due to the pre-adaptation of the cells. The curvature parameter $m$ in the Baranyi and Roberts (1994) model was fixed and set to 1 in the present study.

\subsubsection{Model evaluation}

Model validation is an essential part of model evaluation and conducted to investigate the validity of a model by testing its performance on different data sets than the model was derived from. The indices of model performance bias(Bf) and accuracy- (Af) factors (Ross, 1996) were calculated for Model 1, Model 2 and Model 3 on the basis of $\mu_{m a x}$ values from 11 validation challenge tests at constant temperatures (Table 1; data set \#8-18). A Bf-value of 1.0 indicates an unbiased model, whereas a Bf-value above 1.0 corresponds to a biased model that predicts growth rates to be higher that observed in challenge tests. Bf-values from 0.95 to 1.11 indicates good model performance, whereas $\mathrm{Bf}$-values of 1.11-1.43 and 0.87-0.95 corresponds to acceptable model performance. Bf-values $<0.87$ or $>1.43$ corresponds to unacceptable model performance (Ross, 1999). Af-values > 1.5 indicate incomplete models or systematic deviation between observed and predicted $\mu_{\max }$-values (Mejlholm and Dalgaard, 2013).

Furthermore, the ability of 10 other secondary models to predict the growth rates of L. monocytogenes in fresh ricotta was evaluated by calculation of $\mathrm{Bf}$ and $\mathrm{Af}$ values from $\mu_{\max }$-values in all the 13 calibration and validation challenge tests at constant temperatures (Table 1). The studied existing growth rate models were: the web-based version 
of Combase (Combase, 2012), two web-based models of the PMP software developed for broths (aerobic and anaerobic conditions, respectively), the model by Mejlholm and Dalgaard (2009) previously validated for meat and seafood products and included in the FSSP software, the two cardinal parameter models for respectively liquid dairy and cheese products by Augustin et al. (2005), the two models proposed by Østergaard et al. (2014) for cottage cheese with respectively fresh and cultured cream dressing, the model by Rosshaug et al. (2012) developed for blue-white cheese and the model by Gougouli et al. (2008) validated for ice cream. The characteristics of each ricotta brand, obtained from section 2.1 and the storage conditions measured during each of the challenge tests, were used as input to evaluate the existing models (Table 1 and 2).

Moreover, the acceptable simulation zone (ASZ) approach was used to evaluate the models ability to predict bacterial growth over time and it was done by comparing observed and predicted bacterial concentrations (log CFU g ${ }^{-1}$ ). The acceptable zone was defined as $\pm 0.5 \log \mathrm{CFU} \mathrm{g}^{-1}$ from the predicted growth curve. The model performances of equation (2), equation (3), the recalibrated Mejlholm and Dalgaard (2009) model and the Augustin et al. (2005) model for liquid dairy products were evaluated for independent growth data of L. monocytogenes obtained from 11 validation challenge tests conducted at both constant and dynamic storage temperatures (Table 1, dataset \# 8 to 18). These data were not used to fit or calibrate the evaluated models. When at least $70 \%$ of the observed cell concentrations (log CFU $\mathrm{g}^{-1}$ ) in challenge tests were within ASZ, the prediction was considered acceptable (Møller et al., 2013; Oscar, 2005; Østergaard et al., 2014).

3

\section{Results}

3.1. Microbiological screening of fresh ricotta

The microbiological characterization of fresh ricotta from eight different brands showed that L. monocytogenes was absent in all the samples before inoculation and other types of bacteria were present in low concentrations throughout shelf life of the products. TVC at the beginning of storage (T0) were $<2.7 \log \mathrm{CFU} \mathrm{g}^{-1}$ for all the eight studied brands of fresh ricotta and 37 of the $42 \mathrm{TVC}$ values were below the detection limit of $2.0 \log \mathrm{CFU} \mathrm{g}^{-1}$. At half of the shelf-life (T1), four of the eight brands showed TVC between 2.0 and $3.5 \log$ CFU g ${ }^{-1}$, while the others were below the detection limit. At the end of shelf-life (T2) all the brands had TVC $<4.0 \log \mathrm{CFU} \mathrm{g}{ }^{-1}$. LAB at T1 and T2 were $<$ $2.0 \log \mathrm{CFU} \mathrm{g}^{-1}$. 
The studied fresh ricotta brands showed variability in physical-chemical characteristics (Table 2). The observed average $\mathrm{pH}$ values during storage for the different brands varied between 5.49 and 6.61. Variations were also observed for the concentrations of acetic acid (579 to $2,021 \mathrm{ppm})$, citric acid $(14,774$ to $49,351 \mathrm{ppm})$ and lactic acid (LOQ = $<69.4$ to $4,146 \mathrm{ppm})$. Due to the product $\mathrm{pH}$, approximately $84-99 \%$ of the total acetic acid, $99.6-99.7 \%$ of total citric acid and 97.3-99.8\% of total lactic acid were in the dissociated form. Un-dissociated average concentrations of organic acids were $0.8 \mathrm{mM}$ acetic acid, $0.2 \mathrm{mM}$ citric acid, and $0.1 \mathrm{mM}$ lactic acid at a specific $\mathrm{pH}$ of 6.2 in ricotta. This is important, as the inhibitory effects of organic acids mainly are due to their un-dissociated form (Eklund, 1985; Houstma et al., 1994). Fresh ricotta showed little variability in water activity among brands (0.996-0.998), despite some variability in moisture contents (72.21-82.05\%).

$\mu_{\max }$-values in the challenge tests were, as expected, markedly influenced by the storage temperature (Table 2). The observed $\mu_{\max }$ values increased $\sim 941 \%$ from $0.034 \mathrm{~h}^{-1}$ to $0.320 \mathrm{~h}^{-1}$ when the temperature increased from $4.1^{\circ} \mathrm{C}$ to $20.6^{\circ} \mathrm{C}$. The ability of L. monocytogenes to grow at chill temperature was also confirmed in this study as a $T_{m i n}$-value of -4.06 was determined (Table 3). The variability in $\mathrm{pH}$ between the investigated fresh ricotta brands was sufficient to cause detectable differences in observed $\mu_{\max }$ values of $L$. monocytogenes in the product. At $14.7^{\circ} \mathrm{C}$ the observed $\mu_{\max }$ values dropped $\sim 23 \%$ from $0.197 \mathrm{~h}^{-1}$ to $0.151 \mathrm{~h}^{-1}$ when $\mathrm{pH}$ decreased from 6.61 to 5.49 (Table 2). This was also specifically observed for brand $\mathrm{A}, \mathrm{C}$ and $\mathrm{E}$ at $8.3^{\circ} \mathrm{C}$.

The observed $\log N_{\text {max }}$-values in challenge tests showed little variability with an average value of $8.46 \pm 0.24$

Our experiments (Table 4) carried out to identify the growth boundary (the concentration separating Growth/NoGrowth conditions for undissociated organic acid concentrations) in ricotta showed that at $15.2^{\circ} \mathrm{C}$ ricotta with an undissociated concentration of acetic acid of $8.8 \mathrm{mM}$ (or more) do not support growth of L. monocytogenes within 7 
therefore the MIC value for citric acid was above $24 \mathrm{mM}$ (Table 4). The tested higher levels of citric acid unfortunately had $\mathrm{pH}$ values too close to the growth boundary of $\mathrm{pH}$ for L. monocytogenes according to model 2, and therefore dataset \# 23 and \#24 (Table 1) cannot be used to conclude anything about the effect or citric acid on growth of $L$. monocytogenes in ricotta. Ricotta with an undissociated concentration of lactic acid of $5.1 \mathrm{mM}$ supported growth of $L$. monocytogenes, but not the level of $14.7 \mathrm{mM}$, even though growth should be possible at this $\mathrm{pH}$ value.

Model evaluation

3.5.1 Evaluation of existing models

Several existing predictive models developed in broths or for other dairy products were evaluated for ricotta and some of these were acceptable as shown in Table 6. Augustin et al. (2005) calibrated an extensive cardinal parameter model to L. monocytogenes $\mu_{\max }$-values in liquid dairy products. When applied to fresh ricotta, this model resulted in an acceptable Bf value of 0.88 (Table 6). The acceptable performance of this model was confirmed for storage of different brands of ricotta at constant and dynamic temperature, when using the ASZ method for model evaluation. A mean of $83 \%$ of the challenge test data were within the ASZ (Table 7).

The model proposed by Østergard et al. (2014) for cottage cheese with fresh cream dressing gave acceptable predictions with a slight fail-safe overestimation of growth rates in ricotta $(\mathrm{Bf}=1.18)$ (Table 6). Also the generic Combase model (2012) gave acceptable fail-safe predictions of growth rates in ricotta $(\mathrm{Bf}=1.32)$. These results advised on the potential risks deriving from the use of product specific models for different products.

Other existing models developed for different substrates were tested and unable to accurately predict the growth of L. monocytogenes in fresh ricotta. Some of the models underestimated the growth of this pathogen, showing $\mathrm{Bf}$ ranging from 0.25 to 0.64 , resulting in fail dangerous estimations: (a) The model of Gougouli et al (2008) developed for ice-cream, (b) The model for cheese by Augustin et al. (2005), (c) The model for blue-white cheese by Rosshaug et al (2012), (d) The model for cottage cheese with cultured cream dressing by Østergard et al. (2014). The extensive growth and growth boundary model of Mejlholm and Dalgaard (2009), validated for various seafood and meat products (Mejlholm et al., 2010) markedly underestimated growth rates in fresh ricotta $(\mathrm{Bf}=0.43)$ highlighting the need for evaluation of models with the same type of products where predictions are needed.

3.5.2 Model calibration 
Three models were calibrated to predict growth of $L$ monocytogenes in ricotta. The calibration process resulted

in RMSE values of 0.009 for Model 1 with two fitted parameters; 0.005 for Model 2 with two fitted parameters, and 0.040 for the recalibrated Mejlholm and Dalgaard (2009) model with one fitted parameter. The calibrated parameters $\mu_{\text {ref } 1}$ and $T_{\min }$ for Model $1, \mu_{\text {ref } 2}$ and $p H_{\min }$ for Model 2 and $\mu_{\text {ref } 3}$ in the recalibrated Mejlholm and Dalgaard (2009) model are reported in Table 3.

\subsubsection{Performances of the calibrated models}

The calibrated and thereby product specific models resulted in Bf/Af-values of 1,10/1.11 for Model 1, 1.06/1.09 for Model 2 and 0.78/1.31 for the recalibrated model of Mejlholm and Dalgaard (2009) (Table 6). The good performances of Models 1 and 2 were confirmed for storage of different brands of ricotta at constant and dynamic temperature when using the ASZ method for model evaluation (Figure 1). Mean ASZ scores were $85 \%$ for Model 1 with two challenge tests having below $70 \%$ of the prediction within the ASZ, $91 \%$ for Model 2 with all challenge tests having above $70 \%$ of prediction within ASZ and $65 \%$ for Model 3, with six of the 11 challenge tests having less than $70 \%$ of the prediction within ASZ (Table 7).

\section{Discussion}

The present study allowed characterizing from a chemical-physical and microbiological point of view several brands of Italian fresh ricotta: until this moment limited information about growth characteristics of L. monocytogenes in this product was available in literature (Genigeorgis et al. 1991). This study provided new and quantitative data for the growth potential of L. monocytogenes in ricotta depending on storage temperatures and product characteristics. The new data provided allows potential growth of L. monocytogenes to be evaluated directly in the eight studied brands of ricotta and in general by using the predictive models successfully validated for this substrate in the present study. This is important for the evaluation of the potential growth of $L$. monocytogenes in this product type and to facilitate product reformulation to reduce or prevent growth of this pathogen. Furthermore, very few models that estimates the growth of this pathogen have been validated for dairy products (Augustin et al. 2005 Østergaard et al., 2014), thus this novel model could possibly be convenient also for other fresh dairy products.

The production process of ricotta includes a thermal treatment that can be monitored by the producer, and a hot packaging process including fast sealing of the packages, when the product temperature is still very high. Therefore it is likely that L. monocytogenes is absent when ricotta products leave the dairy with hygienic conditions being maintained. 
Growth of L. monocytogenes in fresh ricotta and the related human health risk, seems particularly important after crosscontamination when the sealed packaging is opened and the product thereafter is handled by consumers including further storage in home-refrigerators. The influence of storage conditions can be critical, because they depend on the behaviour of the consumer. It has to be considered that many RTE products (like ricotta) spend most of their shelf life in a domestic refrigerator; a survey published by the EFSA Panel on Biological Hazards (2007), covering data coming from 7 different European countries, showed high frequencies of improper home refrigeration temperatures, with more than $50 \%$ of temperatures above $6-8^{\circ} \mathrm{C}$. Sealed products are normally safe, but not always, severe listeriosis outbreaks related to other thermally processed foodstuffs with sealed package have been reported. For example, the consumption of cooked ham in Switzerland caused 9 severe listeriosis cases and in Denmark a deli-meat (rullepølse), recently resulted in 17 fatal cases (Hachler et al., 2013; SSI, 2014). For both these outbreaks, a post-process contamination during slicing/packaging and followed by growth of L. monocytogenes is likely. This highlights the importance of both predicting the potential growth of L. monocytogenes in fresh ricotta and considering product reformulation to reduce potential growth.

Of the existing models the most accurate predictions $(\mathrm{Bf} / \mathrm{Af}=0.88 / 1.13)$ were obtained by a cardinal parameter model previously calibrated to $L$. monocytogenes $\mu_{\max }$-values in liquid dairy products and including the effect of temperature, $\mathrm{pH}$ and water activity as well as other factors including nitrite, phenol and $\mathrm{CO}_{2}$ without relevance for ricotta in the present study (Table 6, Augustin et al. 2005). The acceptable performance of the model calibrated to liquid dairy products suggests food structure has little influence on L. monocytogenes growth in ricotta. This is noteworthy as structure has been reported to limit bacterial growth in gels and model soft cheese structured with agar (Wilson et al., 2002; Noriega et al., 2008; Theys et al., 2008). A likely explanation is that the heterogeneous food structure of fresh ricotta contains aqueous pores and cracks where planktonic growth can take place contrary to homogeneous gels based on agar. evaluated predictive models for fermented dairy products are likely to explain part of their underestimation of $L$. monocytogenes growth in fresh ricotta. When calibrated to growth rates in fermented dairy products, the inhibiting effect of bacteriocins or other metabolites will be lumped into the reference growth rate parameter $\left(\mu_{r e f}\right.$ in equation 2 and 3) and in other cardinal parameter models a similar term is often named $\mu_{\text {opt }}$ (Augustin et al. 2005). This was 
recently shown by Østergaard et al. (2014) where $\mu_{r e f}$-values in broth, cottage cheese with fresh cream dressing and cottage cheese with cultured cream dressing were, respectively, $0.67,0.72$ and $0.34 \mathrm{~h}^{-1}$. These data indicates a strong inhibiting effect of the cultured cream dressing and also suggests growth in cottage cheese without cultured cream dressing was as fast as growth in broth.

A model developed for fish and meat products also markedly underestimated growth rates in ricotta $(\mathrm{Bf}=0.43)$ (Table 6). Predictions from this Mejlholm and Dalgaard (2009) model was obtained by taking into account the growth inhibiting effect of acetic, citric and lactic acids as well as the effect of temperature, $\mathrm{pH}$ and $\mathrm{NaCl}$. The combined and observed growth inhibiting effects of acetic, citric and lactic acids in ricotta was much less pronounced than predicted by the Mejlholm and Dalgaard (2009) model and this resulted in the fail-dangerous predictions with $\mathrm{Bf}$ of 0.43 (Table 6)

The new product specific model including only temperature as input variable (Model 1) predicts with good accuracy $(\mathrm{Bf}=1.10)$ the growth of $L$. monocytogenes in a variety of brands of ricotta. This model is useful for a quick simple prediction of growth of $L$. monocytogenes in typical ricotta products, but it does not enable the user to assess the effect on shelf-life of a possible reformulation of product characteristics. In our study the influence of temperature on the growth of L. monocytogenes in ricotta was clearly defined, but also $\mathrm{pH}$ played a role in growth inhibition in this substrate. The variability in $\mathrm{pH}$ between the investigated fresh ricotta brands was sufficient to cause detectable differences in observed $\mu_{\max }$ values of L. monocytogenes in the product. However, the $\mathrm{pH}$ values measured in this study never prevented growth in most of the conducted challenge tests, except for datasets 19, 20, 21, 23, 24 and 27 where additional organic acids were added. Model 2, including the effects of temperature and $\mathrm{pH}$, and with $\mathrm{Bf} / \mathrm{Af}$ of 1.06/1.09 was successfully validated for to predict growth of L. monocytogenes in fresh ricotta. Model 2 did not included terms to describe the inhibiting effect of organic acids in fresh ricotta (Equation (2)). The inhibiting effect of organic acids in fresh ricotta was therefore lumped into the fitted parameters in Model 2 and this may explains the relatively high observed parameter value for $p H_{\min }$ of 4.91 describing the combined effect of $\mathrm{pH}$ and organic acids in the studied fresh ricotta.

The estimated cardinal parameter values $\left(T_{\min }=-4.06^{\circ} \mathrm{C} ; p H_{\min }=4.91\right)$ corresponded partially to literature values .

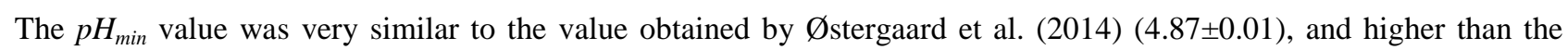
values observed by Augustin et al. (2005) from a model for liquid microbiological media, both with hydrochloric (4.26 \pm 0.24$)$ or lactic acid as acidulant $(4.71 \pm 0.28)$. Considering the $T_{\min }$ values, the result obtained in our study was evidently lower than those obtained in the two studies cited $\left(-2.01 \pm 0.40\right.$ and $-1.72 \pm 2.55^{\circ} \mathrm{C}$, respectively). These results 
suggested the specificity of ricotta substrate, with a strict $\mathrm{pH}$ range for L. monocytogenes growth and a less evident inhibition of growth rate when temperatures are getting lower.

The successfully validated Model 2 and the model of Augustin et al. (2005) can be used to assess the safe shelf life of ricotta depending on storage temperature and product $\mathrm{pH}$ and finally to reformulate the product. Considering, as an example, an open package of ricotta $(\mathrm{pH} \sim 6.2)$ contaminated with L. monocytogenes to a concentration of $1 \mathrm{CFU} \cdot \mathrm{g}^{-1}$ and stored in a household refrigerators $\left(7^{\circ} \mathrm{C}\right.$ ), to avoid exceedance of the limit of $100 \mathrm{CFU} \mathrm{g}{ }^{-1}$ or $2 \log \mathrm{CFU} \mathrm{g} \mathrm{g}^{-1}(\mathrm{EC}$, 2005), shelf life should not exceed 3-4 days (Table 8). A reduction of the product $\mathrm{pH}$ to 5.8, combined with a decrease in storage temperature $\left(4^{\circ} \mathrm{C}\right)$ allowed to extend the predicted safe shelf life up to 6-10 days. These results confirmed the importance of good practices for consumers requiring a correct refrigeration and consumption of ricotta in few (twothree) days after opening of the packaging; labels providing consumers instructions on how long a RTE product like ricotta could be stored and when to discard after opening the package are helpful and well established (Lenart et al., 2008).

A generic predictive model that can be used for many food products is interesting, easier to use and may be more valuable than a product specific model where accurate predictions can be restricted to a particular food. However, the extensive Mejlholm and Dalgaard (2009) model that has been successfully validated for a range of seafood and meat products (Mejlholm et al. 2010) markedly under-predicted growth rates of L. monocytogenes in ricotta $(\mathrm{Bf}=0.43)$ highlighting the need for product specific predictive models (Table 6). With $\mu_{\text {ref }}$ recalibrated to L. monocytogenes $\mu_{\max }{ }^{-}$ values in fresh ricotta this model performed better $(\mathrm{Bf}=0.78)$ but it was still not acceptable for this product. Calibrating $\mu_{r e f}$ and MICs for acetic, citric and lactic acids in the Mejlholm and Dalgaard (2009) model to ricotta datasets \# 1-13 (Table 1) and with $\mu_{\max }$-values as shown in Table 2 resulted in a $\mu_{\text {ref }}$-value of 0.523, RMSE of 0.008 and MIC-value of above $1000 \mathrm{mM}$ of all three undissociated acids (Results not shown). This confirms that there is practically no inhibiting effect against growth of L. monocytogenes for the three organic acids in fresh ricotta as shown above by the ability to predict growth accurately by simple models not including the inhibiting effects of acetic, citric and lactic acids (Table 6 and 7). This also explains the poor performance of the original Mejlholm and Dalgaard (2009) model $(\mathrm{Bf}=$ 0.43 ) as the acetic, citric and lactic acid concentrations in fresh ricotta results in reduced predicted $\mu_{\max }$-values values for L. monocytogenes.

MIC values determined in the present study for undissociated acetic and lactic acids were similar to those reported in literature (Table 5, Coroller et al., 2005; Le Marc et al., 2002; Mejlholm and Dalgaard, 2009; Wemmenhove et al. 2016). However, a much higher MIC value was found for citric acid (Table 5) this could be related to differences 
in substrate when determining these values: the MIC-value suggested by Le Marc et al. (2002), Coroller et al. (2005) and Mejlholm and Dalgaard (2009) were measured in broths, while our data were obtained from ricotta substrates.

For lactic acid bacteria a previous study reported that MICs determined from challenge tests in real foods were 2-3 times higher than MICs determined for broth (Mejlholm and Dalgaard, 2013). Importantly, they found MIC values determined from challenge tests with brined shrimps resulted in a good model performance whereas this was not the case for MICs determined by using APT broth. We have found no previous reports of very high MIC values as suggested by the present study for acetic, citric and lactic acid in fresh ricotta. It remains to be determined why MIC values apparently can depend on the type of substrate as also previously pointed out for brined shrimps (Mejlholm and Dalgaard, 2013). Future studies should be performed in order to understand mechanisms of action and the quantitative influence of temperature on MICs, that remains uncertain.

In conclusion, the present study provided new data and validated predictive models to define the growth potential of L. monocytogenes in fresh ricotta as relevant for safe shelf-life and to reformulate the product for increased shelf-life or safety. This would be extremely advantageous especially in the reformulation of ricotta by the manufacturers, with important social and economic returns.

\section{Acknowledgements}

The authors would like to thank Jeppe Boel (Technical University of Denmark) and Arla Food for providing the $L$. monocytogenes strains used in this study.

\section{References}

Adams, M.R., Moss, M.O., 2000. Food Microbiology. Second ed. Royal Society of Chemistry.

AFNOR - Association Française de Normalisation, 2001. Rapid L'mono enumeration method. AFNOR BRD 07/05$09 / 01$. 
Assolatte, 2014. Ricotta: Immancable a pasqua, in crescita tutto l'anno. Available at: http://www.assolatte.it/zpublish/4/uploads/4/news_down/13712676276132994022_com_ricotta.pdf（Accessedｏn 481 January 7, 2016).

482 Augustin, J.-C., Carlier, V., 2000a. Mathematical modelling of the growth rate and lag time for Listeria monocytogenes. Int. J. Food Microbiol. 56, 29-51.

Augustin, J.-C., Carlier, V., 2000b. Modelling the growth rate of Listeria monocytogenes with a multiplicative type model including interactions between environmental factors. Int. J. Food Microbiol. 56, 53-70.

Augustin, J.-C., Zuliani, V., Cornu, M., Guillier, L., 2005. Growth rate and growth probability of Listeria monocytogenes in dairy, meat and seafood products in suboptimal conditions. J. Appl. Microbiol. 99, 1019-1042.

Baranyi, J., Roberts, T.A., 1994. A dynamic approach to predicting bacterial growth in food. Int. J. Food Microbiol. 23, 277-294.

Bradley, R.L.,Vanderwarn, M.A., 2001. Determination of moisture in cheese and cheese products. J. AOAC Int. 84, 570-592.

ComBase, 2012. Web-based resource for Quantitative and Predictive Food Microbiology. Available at: http://www.combase.cc/index.php/en/ (Accessed on July 6 2015).

494 Coroller, L., Guerrot, V., Huchet, V., Le Marc, Y., Mafart P., Sohier, D., Thuault, D., 2005. Modelling the influence of single acid and mixture on bacterial growth. Int. J. Food Microbiol. 100, 167-178.

De Buyser, M.-L., Dufour, B., Maire, M., Lafarge, V., 2001. Implication of milk and milk products in food-borne disease in industrialised countries. Int. J. Food Microbiol. 67, 1-17.

498 EC - European Commission, 2005. European Commission Regulation (EC) No 2073/2005 of 15 November 2005 on microbiological criteria for foodstuffs. O.J.E.U. L 338/1. hydroxybenzoic acid. Int. J. Food Microbiol. 2, 159-167. 
Farkye, N.Y., 2004. Acid- and Acid/Rennet-curd Cheeses. Part C: Acid-heat Coagulated Cheeses, in: Fox, P.F., McSweeney, P.L.H., Cogan, T.M., Guinee, T.P. (Eds.), Cheese Chemistry, Physics and Microbiology. Elsevier Academic Press, Oxford, pp. 343-348.

FSSP (Food Spoilage and Safety Predictor). National Food Institute (DTU Food), Technical University of Denmark. Available at: http://fssp.food.dtu.dk/ (Accessed on July 6 2015).

Genigeorgis, C., Carniciu, M., Dutulescu, D., Farver, T.B., 1991. Growth and survival of Listeria monocytogenes in market cheese stored at 4 and $30^{\circ}$ C. J. Food Protect. 54, 662-668.

Giménez, B., Dalgaard, P., 2004. Modelling and predicting the simultaneous growth of Listeria monocytogenes and spoilage micro-organisms in cold-smoked salmon. J. Appl. Microbiol. , 96, 96-109.

Gougouli, M., Angelidis, A.S., Koutsoumanis, K., 2008. A Study on the kinetic behavior of Listeria monocytogenes in ice cream stored under static and dynamic chilling and freezing conditions. J. Dairy Sci. 91, 523-530.

Hächler, H., Marti, G., Giannini, P., Lehner, A., Jost, M., Beck, J., Weiss, F., Bally, B., Jermini, M., Stephan, R., Baumgartner, A., 2013. Outbreak of listeriosis due to imported cooked ham, Switzerland 2011. Euro Surveill. 18, 20469. Available at http://www.eurosurveillance .org/ViewArticle.aspx?ArticleId=20469 (Acessed on January 72016 ).

Houstma, P.C., Kusters, B.J.M., De Witt, J.C., Rombouts, F.M., Zwietering, M.H, 1994. Modelling growth rates of Listeria innocua as a function of lactate concentration, Int. J. Food Microbiol. 24, 113-123

Houtsma, P.C., Kant-Muermans, M.L., Rombouts, F.M., Zwietering, F.H., 1996. Model for the combined effects of temperature, $\mathrm{pH}$, and sodium lactate on growth rates of Listeria innocua in broth and Bologna-type sausages. Appl. Environ. Microbiol. 62, 1616-1622.

ICH Topic Q 2 (R1),1995. Validation of Analytical Procedures: Note for guidance on validation of analytical procedures: text and methodology (CPMP/ICH/381/95). European Medicines Agency (Emea).

Lenhart, J., Kendall, P., Medeiros, L., Doorn, J., Schroeder, M., Sofos, J., 2008. Consumer assessment of safety and date labeling statements on ready-to-eat meat and poultry products designed to minimize risk of listeriosis. J. Food Prot., 71, 70-6. 
Le Marc, Y., Huchet, V., Bourgeois, C.M., Guyonnet, J.P., Mafart, P., 2002. Modelling the growth kinetics of Listeria as a function of temperature, $\mathrm{pH}$ and organic acid concentration. Int. J. Food Microbiol. 73, 219 - 237.

Little, C.L., Rhoades, J.R., Sagoo, S.K., Harris, J., Greewood, M., Mithani, V., Grant, K., McLauchlin, J., 2008. Microbiological quality of retail cheeses made from raw, thermized or pasteurized milk in the UK. Food Microbiol. 25, 304-312.

Lundèn, J., Tolvanen, R., Korkeala, H., 2004. Human listeriosis outbreaks linked to dairy products in Europe. J. Dairy Sci. 87, E6-E11.

Martinez-Rios, V., Dalgaard, P., 2018. Prevalence of Listeria monocytogenes in European cheeses: A systematic review and meta-analysis. Food Cont. 84, 205-214.

Mejlholm, O., Bøknæs, N., Dalgaard, P., 2015. Development and validation of a stochastic model for potential growth of Listeria monocytogenes in naturally contaminated lightly preserved seafood. Food Microbiol. 45, 276-289.

Mejlholm, O., Dalgaard, P., 2009. Development and validation of an extensive growth and growth boundary model for Listeria monocytogenes in lightly preserved and ready-to-eat shrimp. J. Food Protect. 72, 2132-2143.

Mejlholm, O., Gunvig, A., Borggaard, C. Blom-Hanssen, J., Mellefont, L., Ross, T., Leroi, F., Else, T., Visser, D., Dalgaard, P., 2010. Predicting growth rates and growth boundary of Listeria monocytogenes - An international validation study with focus on processed and ready-to-eat meat and seafood. Int. J. Food Microbiol. 141, 137-150.

Mejlholm, O., Dalgaard, P., 2013. Development and validation of an extensive growth and growth boundary model for psychrotolerant Lactobacillus spp. in seafood and meat products. Int. J. Food Microbiol. 167, 244-260.

Møller, C.O.A., Ilg, Y., Aabo, S., Christensen, B.B., Dalgaard, P., 2013. Effect of natural microbiota on growth of Salmonella spp. in fresh pork. A predictive microbiology approach. Food Microbiol. 34, 284-295.

Mucchetti, G., Neviani, E., 2006. Microbiologia e tecnologia lattiero-casearia. Qualità e Sicurezza. Tecniche Nuove, Milan, pp. 363-382.

Oliver, S.P., Jayarao, B.M., Almeida, R.A., 2005. Foodborne pathogens in milk and the dairy farm environment: Food safety and public health implications. A review. Foodborne Pathog Dis, 2: 115-129. 
Oscar, T.P., 2005. Validation of lag time and growth rate models for Salmonella Typhimurium: acceptable prediction zone method. J. Food Sci. 70, M129-M137.

Østergaard, N.B., Eklöw, A., Dalgaard, P., 2014. Modelling the effect of lactic acid bacteria from starter- or aroma culture on growth of Listeria monocytogenes in cottage cheese. Int. J. Food Microbiol. 188, 15-25.

Panagou, E.Z., Nychas, G.-H. E., 2008. Dynamic modeling of Listeria monocytogenes growth in pasteurized vanilla cream after postprocessing contamination. J. Food Protect. 71, 1828-1834.

Pearson, D., 1973. Laboratory Techniques in Food Analysis. Butterworths \& Co. Publishers, London, pp. 201-202. University Press, Cambridge, UK.

Presser, K.A., Ratkowsky, D.A., Ross, T., 1997. Modelling the growth rate of Escherichia coli as a function of pH and lactic acid concentration. Appl. Environ. Microbiol. 63, 2355-2360.

RASFF - Rapid Alert System for Food and Feed, 2015. Available at https://webgate.ec.europa.eu/rasffwindow/portal/?event=SearchForm\&cleanSearch=1 (Accessed on May 25 2018).

563 Ratkowsky, D.A., Olley, J., McMeekin, T.A., Ball, A. 1982. Relationship between temperature and growth rate of 564 bacterial cultures. J. Bacteriol. 149, 1-5.

Robins, M.M., Wilson, P.D.G., 1994. Food structure and microbial growth. Trends Food Sci. Tech. 5, 289-293.

Ross, T., 1996. Indices for performance evaluation of predictive models in Food Microbiology. J. Appl. Bacteriol. 81, $567 \quad 501-508$.

568 Ross, T., 1999. Predictive Food Microbiology Models in the Meat Industry. Meat and Livestock Australia, Sydney, p. 569196. blue-white cheese. Appl. Environ. Microbiol. 78, 8508-8514. 
572 Sattin, E., Andreani, N.A., Carraro, L., Fasolato, L., Balzan, S., Novelli, E., Squartini, A, Telatin, A., Simionati, B., 573 Cardazzo, B., 2016. Microbial dynamics during shelf-life of industrial Ricotta cheese and identification of 574 a Bacillus strain as a cause of a pink discolouration. Food Microbiol. 57, 8-15.

575 SSI - Statens Serum Institute, 2014. Listeria outbreak - suspected source: deli meats. Available at 576 http://www.ssi.dk/English/News/News/2014/2014_08_listeria.aspx (Accessed on January 72016 ).

577 Tormo, M., Izco, J.M., 2004. Alternative reversed-phase high-performance liquid chromatography method to analyse 578 organic acids in dairy products. J. Chromatog. A 1033, 305-310.

579 USDA - United States Department of Agriculture, 2013. Pathogen Modelling Program (PMP). Available at: 580 http://pmp.arserrc.gov/PMPOnline.aspx. (Accessed July 6, 2015).

581 Wilson, P.D.G, Brocklehurst, T.F., Arino, S., Thuault, D., Jakobsen, M., Lange, M., Farkas, J., Wimpenny, J.W.T., 582 Van Impe, J.F., 2002. Modelling microbial growth in structured foods: towards a unified approach. Int. J. Food 583 Microbiol. 73, 275-289.

584 Zottola E.A., Smith L.B. 1991. Pathogens in cheese. Food Microbiol. 8, 171-182. 


\section{$585 \quad$ Figure 1}

586 Comparison of observed ( $(\mathbf{)})$ and predicted (-) growth for L. monocytogenes in three brands of fresh ricotta. Data set $587 \quad \# 16$ (A), data set \#15 (B) and data set \#14 (C). Predictions and the acceptable simulation zone (…..) were obtained by 588 using Model 2 including the effect of temperature and $\mathrm{pH}$. Temperature profiles are illustrated with grey lines. 
1 Table 1

2 Challenge tests with L. monocytogenes in ricotta and application of data for model calibration, model validation and 3 assessment of MIC (minimum inhibitory concentration) values for organic acids

\begin{tabular}{|c|c|c|c|c|c|}
\hline $\begin{array}{l}\text { Data- } \\
\text { set \# }\end{array}$ & $\begin{array}{l}\text { Use of } \\
\text { dataset }\end{array}$ & $\begin{array}{l}\text { Average storage } \\
\text { temperature }\left({ }^{\circ} \mathrm{C}\right)\end{array}$ & $\begin{array}{c}\text { No. of } \\
\text { sampling } \\
\text { times }^{\mathrm{a}}\end{array}$ & $\begin{array}{c}\text { Temperature } \\
\text { variability }\end{array}$ & $\begin{array}{c}\text { Product } \\
\text { brand code }\end{array}$ \\
\hline 1 & Calibration & 4.1 & 29 & Static & $\mathrm{A}$ \\
\hline 2 & Calibration & 8.3 & 21 & Static & $\mathrm{C}$ \\
\hline 3 & Calibration & 8.3 & 21 & Static & $\mathrm{E}$ \\
\hline 4 & Calibration & 13.4 & 12 & Static & $\mathrm{D}$ \\
\hline 5 & Calibration & 20.6 & 12 & Static & B \\
\hline 6 & Calibration & 14.7 & 8 & Static & G \\
\hline 7 & Calibration & 14.7 & 7 & Static & $\mathrm{G}$ with added acetic acid \\
\hline 8 & Validation & 8.3 & 21 & Static & 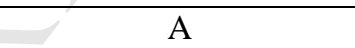 \\
\hline 9 & Validation & 10.3 & 20 & Static & A \\
\hline 10 & Validation & 13.4 & 12 & Static & A \\
\hline 11 & Validation & 14.7 & 8 & Static & $\mathrm{G}$ with added citric acid \\
\hline 12 & Validation & 14.7 & 8 & Static & $\mathrm{G}$ with added lactic acid \\
\hline 13 & Validation & 20.6 & 12 & Static & A \\
\hline 14 & Validation & 5.6 & 16 & Dynamic $4-8^{\circ} \mathrm{C}$ & $\mathrm{F}$ \\
\hline 15 & Validation & 5.6 & 16 & Dynamic $4-8{ }^{\circ} \mathrm{C}$ & $\mathrm{H}$ \\
\hline 16 & Validation & 5.9 & 16 & Dynamic $4-8{ }^{\circ} \mathrm{C}$ & A \\
\hline 17 & Validation & 13.5 & 14 & Dynamic $12-16{ }^{\circ} \mathrm{C}$ & A \\
\hline 18 & Validation & 13.5 & 14 & Dynamic $12-16{ }^{\circ} \mathrm{C}$ & $\mathrm{G}$ \\
\hline 19 & Assess MIC & 15.2 & 2 & Static & $\mathrm{G}$ with added acetic acid \\
\hline 20 & value for & 15.2 & 2 & Static & $\mathrm{G}$ with added acetic acid \\
\hline 21 & acetic acid & 15.2 & 2 & Static & $\mathrm{G}$ with added acetic acid \\
\hline 22 & Assess MIC & 15.2 & 2 & Static & $\mathrm{G}$ with added citric acid \\
\hline 23 & value for & 15.2 & 2 & Static & $\mathrm{G}$ with added citric acid \\
\hline 24 & citric acid & 15.2 & 2 & Static & $\mathrm{G}$ with added citric acid \\
\hline 25 & Assess MIC & 15.2 & 2 & Static & $\mathrm{G}$ with added lactic acid \\
\hline 26 & value for & 15.2 & 2 & Static & $\mathrm{G}$ with added lactic acid \\
\hline 27 & lactic acid & 15.2 & 2 & Static & $\mathrm{G}$ with added lactic acid \\
\hline
\end{tabular}

$5{ }^{\mathrm{a}}$ At each sampling time analyses were performed in triplicate 
6 Table 2 Observed kinetics parameters of L. monocytogenes in ricotta and environmental conditions measured for each challenge test

\begin{tabular}{|c|c|c|c|c|c|c|c|c|c|c|c|c|c|}
\hline \multirow[b]{2}{*}{$\begin{array}{c}\text { Dataset } \\
\quad \#\end{array}$} & \multirow{2}{*}{$\begin{array}{l}\text { Product } \\
\text { brand } \\
\text { code }\end{array}$} & \multirow[b]{2}{*}{$\begin{array}{c}\text { Temperature } \\
\left({ }^{\circ} \mathrm{C}\right) \\
(\mathrm{AVG} \pm \mathrm{SD})\end{array}$} & \multirow[b]{2}{*}{$\begin{array}{c}\mathrm{pH} \mathrm{T0} \\
(\mathrm{AVG} \pm \mathrm{SD})\end{array}$} & \multirow[b]{2}{*}{$\begin{array}{l}\mathrm{pH} \text { T final } \\
(\mathrm{AVG} \pm \mathrm{SD})\end{array}$} & \multirow{2}{*}{$\begin{array}{c}\text { Moisture } \\
\text { content } \\
(\%) \\
(\mathrm{AVG} \pm \mathrm{SD})\end{array}$} & \multirow[b]{2}{*}{$\begin{array}{c}\mathrm{WPS}^{\mathrm{b}} \\
(\%)\end{array}$} & \multicolumn{4}{|c|}{$\begin{array}{l}\text { Organic acid concentration in the water phase of } \\
\text { the products }(\mathrm{ppm})(\mathrm{AVG} \pm \mathrm{SD})\end{array}$} & \multirow[b]{2}{*}{$\begin{array}{c}\mu_{\max }\left(\mathrm{h}^{-1}\right. \\
\mathrm{AVG} \pm \mathrm{SD})\end{array}$} & \multirow[b]{2}{*}{$\begin{array}{l}\text { Lag time } \\
\text { (h) }\end{array}$} & \multirow[b]{2}{*}{$\begin{array}{c}N_{\max } \\
\left(\log \mathrm{CFU} \mathrm{g}{ }^{-1}\right. \\
\mathrm{AVG} \pm \mathrm{SD})\end{array}$} \\
\hline & & & & & & & $a_{w}$ & Acetic acid & Citric acid & Lactic acid & & & \\
\hline 1 & $\mathrm{~A}$ & $4.1 \pm 0.2$ & $6.07 \pm 0.08$ & $5.95 \pm 0.02$ & $74.6 \pm 0.54$ & 0.41 & 0.997 & $1,559 \pm 62$ & $46,116 \pm 1,314$ & $3,187 \pm 349$ & $0.034 \pm 0.000$ & $\mathrm{NS}^{\mathrm{c}}$ & $8.62 \pm 0.02$ \\
\hline 2 & $\mathrm{C}$ & $8.3 \pm 0.2$ & $6.52 \pm 0.08$ & $6.43 \pm 0.11$ & $78.7 \pm 0.19$ & 0.20 & 0.998 & $1,210 \pm 241$ & $32,536 \pm 3,308$ & $2,425 \pm 471$ & $0.077 \pm 0.001$ & $\mathrm{NS}^{\mathrm{c}}$ & $8.73 \pm 0.07$ \\
\hline 3 & $\mathrm{E}$ & $8.3 \pm 0.2$ & $6.49 \pm 0.10$ & $6.38 \pm 0.06$ & $79.3 \pm 0.51$ & 0.42 & 0.997 & $1,331 \pm 105$ & $32,909 \pm 937$ & $2,316 \pm 186$ & $0.073 \pm 0.001$ & $\mathrm{NS}^{\mathrm{c}}$ & $8.62 \pm 0.04$ \\
\hline 4 & $\mathrm{D}$ & $13.4 \pm 0.2$ & $6.22 \pm 0.07$ & $5.61 \pm 0.09$ & $82.1 \pm 0.87$ & 0.37 & 0.998 & $921 \pm 301$ & $30,820 \pm 13,875$ & $3,878 \pm 794$ & $0.162 \pm 0.005$ & $\mathrm{NS}^{\mathrm{c}}$ & $8.33 \pm 0.08$ \\
\hline 5 & B & $20.6 \pm 0.2$ & $5.95 \pm 0.11$ & $5.78 \pm 0.04$ & $72.5 \pm 0.52$ & 0.36 & 0.998 & $1,345 \pm 150$ & $42,491 \pm 2,643$ & $2,929 \pm 502$ & $0.310 \pm 0.038$ & $\mathrm{NS}^{\mathrm{c}}$ & $8.30 \pm 0.02$ \\
\hline 6 & $\mathrm{G}$ & $14.7 \pm 0.1$ & $6.61 \pm 0.06$ & $6.53 \pm 0.03$ & $77.5 \pm 0.30$ & 0.60 & 0.996 & $660 \pm 14$ & $14,774 \pm 245$ & $<69.4$ & $0.197 \pm 0.012$ & $\mathrm{NS}^{\mathrm{c}}$ & $8.48 \pm 0.00$ \\
\hline 7 & $\mathrm{G}^{\mathrm{d}}$ & $14.3 \pm 0.1$ & $5.69 \pm 0.18$ & $5.91 \pm 0.12$ & $77.3 \pm 0.65$ & 0.60 & 0.996 & $1,153 \pm 401$ & $17,867 \pm 7029$ & $641 \pm 411$ & $0.156 \pm 0.107$ & $59.2 \pm 37.4$ & $7.58 \pm 1.39$ \\
\hline 8 & A & $8.3 \pm 0.2$ & $6.15 \pm 0.07$ & $5.94 \pm 0.08$ & $75.5 \pm 0.53$ & 0.41 & 0.997 & $1,513 \pm 96$ & $36,119 \pm 1,750$ & $3,270 \pm 300$ & $0.064 \pm 0.001$ & $\mathrm{NS}^{\mathrm{c}}$ & $8.64 \pm 0.03$ \\
\hline 9 & A & $10.3 \pm 0.2$ & $6.12 \pm 0.07$ & $5.82 \pm 0.02$ & $74.4 \pm 0.13$ & 0.41 & 0.997 & $1,582 \pm 225$ & $49,272 \pm 5,263$ & $2,534 \pm 795$ & $0.093 \pm 0.001$ & $\mathrm{NS}^{\mathrm{c}}$ & $8.54 \pm 0.06$ \\
\hline 10 & A & $13.4 \pm 0.2$ & $6.14 \pm 0.12$ & $5.84 \pm 0.04$ & $75.0 \pm 0.35$ & 0.41 & 0.997 & $2,021 \pm 74$ & $49,351 \pm 2,850$ & $4,004 \pm 136$ & $0.150 \pm 0.004$ & $\mathrm{NS}^{\mathrm{c}}$ & $8.25 \pm 0.02$ \\
\hline 11 & $\mathrm{G}^{\mathrm{e}}$ & $14.7 \pm 0.1$ & $5.70 \pm 0.15$ & $5.73 \pm 0.15$ & $77.9 \pm 2.79$ & 0.60 & 0.996 & $579 \pm 22$ & $34,994 \pm 2296$ & $396 \pm 199$ & $0.168 \pm 0.003$ & $N S^{c}$ & $7.99 \pm 0.17$ \\
\hline 12 & $\mathrm{G}^{\mathrm{f}}$ & $14.7 \pm 0.1$ & $5.49 \pm 0.18$ & $5.61 \pm 0.11$ & $78.2 \pm 1.00$ & 0.60 & 0.996 & $668 \pm 45$ & $15,903 \pm 2787$ & $4,146 \pm 1825$ & $0.151 \pm 0.019$ & $\mathrm{NS}^{\mathrm{c}}$ & $7.85 \pm 0.08$ \\
\hline 13 & $\mathrm{~A}$ & $20.6 \pm 0.2$ & $6.05 \pm 0.14$ & $5.58 \pm 0.04$ & $75.0 \pm 0.35$ & 0.41 & 0.997 & $1,725 \pm 221$ & $46,779 \pm 5,446$ & $3,414 \pm 587$ & $0.320 \pm 0.099$ & $\mathrm{NS}^{\mathrm{c}}$ & $8.20 \pm 0.08$ \\
\hline 15 & $\mathrm{H}$ & $5.6 \pm 1.9$ & $6.56 \pm 0.10$ & $6.27 \pm 0.11$ & $77.2 \pm 0.45$ & 0.38 & 0.998 & $1,051 \pm 71$ & $27,456 \pm 463$ & $2,600 \pm 178$ & g & $-g$ & _g \\
\hline 16 & A & $5.9 \pm 1.9$ & $6.12 \pm 0.09$ & $6.17 \pm 0.05$ & $74.5 \pm 0.10$ & 0.41 & 0.997 & $1,696 \pm 452$ & $48,956 \pm 569$ & $3,352 \pm 752$ & gg & gg & _g \\
\hline 17 & $\mathrm{~A}$ & $13.5 \pm 2.1$ & $6.07 \pm 0.11$ & $5.68 \pm 0.03$ & $74.4 \pm 0.17$ & 0.41 & 0.997 & $1,977 \pm 77$ & $50,862 \pm 967$ & $4,138 \pm 316$ & gg & gg & -g \\
\hline 18 & $\mathrm{G}$ & $13.5 \pm 2.1$ & $6.61 \pm 0.11$ & $6.14 \pm 0.12$ & $72.2 \pm 0.24$ & 0.60 & 0.996 & $852 \pm 66$ & $20,465 \pm 917$ & $306 \pm 256$ & _g & $-g$ & _g \\
\hline
\end{tabular}

$8{ }^{\mathrm{a}}$ Average of values in exponential growth phase;

$9{ }^{\mathrm{b}} \mathrm{NaCl}$ in the water phase (WPS);

$10{ }^{\mathrm{c}}$ Not significant (NS);

11 d Acetic acid added;

12 e Citric acid added;

$13{ }^{\mathrm{f}}$ Lactic acid added.

$14{ }^{\mathrm{g}}$ Not applicable 
Table 3 Fitted model parameters

16

\begin{tabular}{llll}
\hline Model \# & Parameter values & $\begin{array}{l}95 \% \text { Confidence } \\
\text { interval }\end{array}$ & RMSE/R \\
\hline 1 & $\begin{array}{l}\mu_{\text {ref } 1}=0.433 \mathrm{~h}^{-1} \\
T_{\min }=-4.06^{\circ} \mathrm{C}\end{array}$ & $0.415-0.451 \mathrm{~h}^{-1}$ & $0.009 / 0.988$ \\
\hline 2 & $\begin{array}{l}\mu_{\text {ref } 2}=0.471 \mathrm{~h}^{-1} \\
p H_{\text {min }}=4.91\end{array}$ & $0.451-0.491 \mathrm{~h}^{-1}$ & $0.005 / 0.997$ \\
\hline 3 & $\mu_{\text {ref } 3}=0.808 \mathrm{~h}^{-1}$ & $0.774-0.842 \mathrm{~h}^{-1}$ & $0.040 / 0.794$ \\
\hline
\end{tabular}

17 
Table 4 Observed growth or no-growth of L. monocytogenes in fresh ricotta with added organic acids

\section{9}

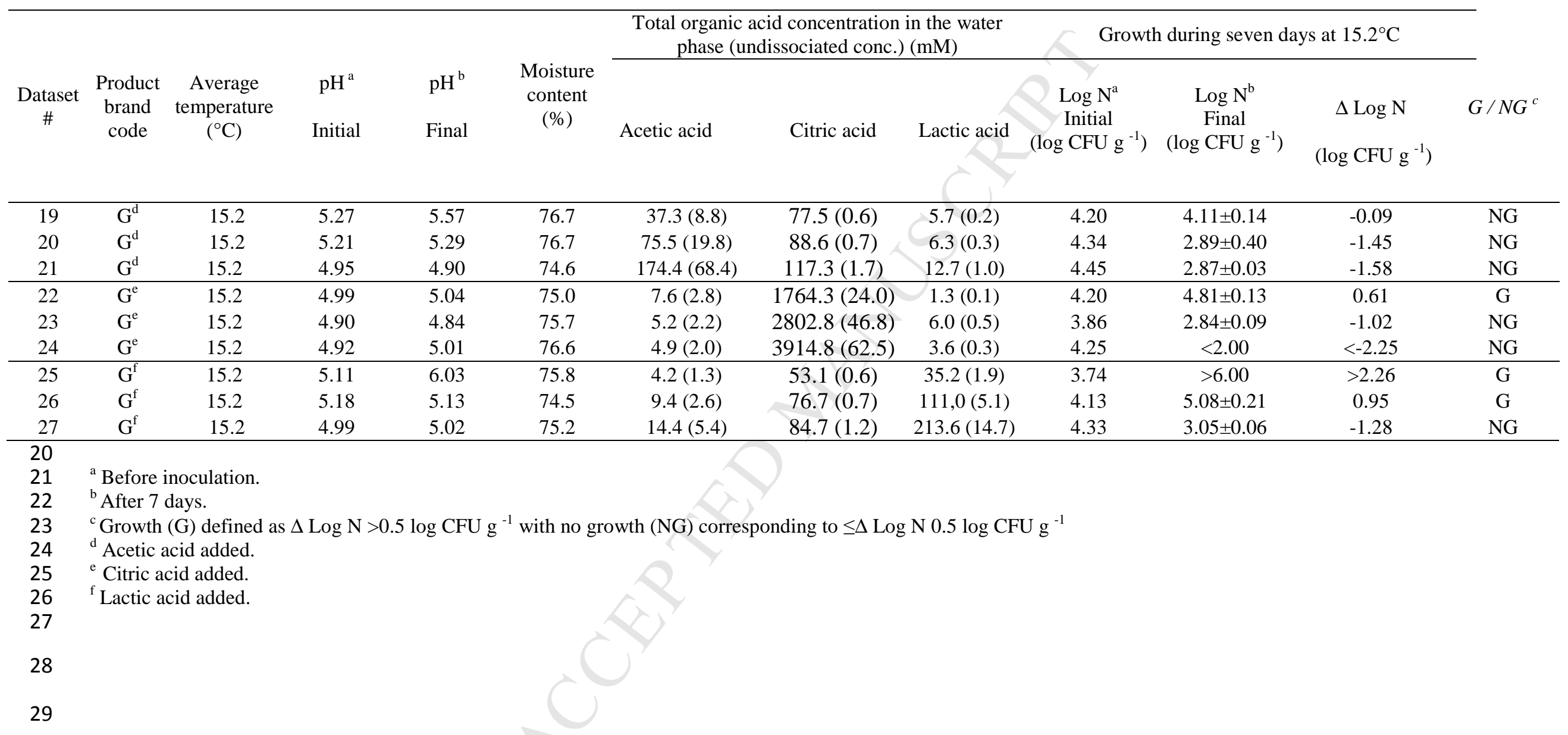


Table 5 MIC values for un-dissociated concentrations of acetic acid, citric acid, and lactic acid in different substrates

\begin{tabular}{|c|c|c|c|c|c|c|}
\hline \multirow{2}{*}{ References } & \multicolumn{3}{|c|}{ MIC Undissociated acid (mM) } & \multirow{2}{*}{ Substrate } & \multirow{2}{*}{$\begin{array}{c}\text { Temp. } \\
\left({ }^{\circ} \mathrm{C}\right)\end{array}$} & \multirow{2}{*}{ Species } \\
\hline & Citric acid & Acetic acid & Lactic acid & & & \\
\hline Present study & $>24.0$ & $<8.8$ & $5.1-14.7$ & Fresh ricotta & 15.2 & L. monocytogenes \\
\hline Coroller et al. 2005 & $0.2-3.6$ & 21.5 & 6.4 & BHI & 30 & L. innocua \\
\hline Le Marc et al., 2002 & $-^{a}$ & 20.3 & 8.0 & Modified BHI & 20 & L. innocua \\
\hline Mejlholm and Dalgaard, 2009 & 2.12 & 10.3 & 3.79 & BHI pH 6.0 & 8 & L. monocytogenes \\
\hline Wemmenhove et al., 2016 & $3.8 \pm 0.9$ & $19.0 \pm 6.5$ & $5.0 \pm 1.5$ & BHI at $\mathrm{pH} 4.6-5.8$ & $30^{\circ} \mathrm{C}$ & L. monocytogenes \\
\hline
\end{tabular}

${ }^{a}$ Not determined 
Table 6 Performance evaluation of growth models for L. monocytogenes applied for fresh ricotta.

\begin{tabular}{|c|c|c|c|c|c|}
\hline Reference/Software & $\mathrm{n}^{\mathrm{a}}$ & Substrate & Variables included $^{\mathrm{b}}$ & $\overline{\mathrm{Bf}}$ & Af \\
\hline PMP (aerobic) (USDA, 2013) & 13 & Broth & $T, p H, \quad N a C l,(N I T)$ & 1.86 & 1.86 \\
\hline PMP (anaerobic) (USDA, 2013) & 13 & Broth & $T, p H, N a C l,(N I T)$ & 2.01 & 2.01 \\
\hline Combase (2012) & 13 & Broth/Food & $T, p H, A w$ & 1.32 & 1.32 \\
\hline Gougouli et al., 2008 & 13 & Ice cream & $T$ & 0.64 & 1.56 \\
\hline Rosshaug et al., 2012 & 13 & $\begin{array}{l}\text { Blue-white } \\
\text { cheese }\end{array}$ & T, $p H, L A C, \mathrm{NaCl}$ & 0.37 & 2.71 \\
\hline Østergaard et al., 2014 & 13 & $\begin{array}{l}\text { Cottage cheese- } \\
\text { fresh cream }\end{array}$ & $A w, L A C,(S A C)$ & 1.18 & 1.28 \\
\hline Østergaard et al., 2014 & 13 & $\begin{array}{l}\text { Cottage cheese- } \\
\text { cultured cream }\end{array}$ & $\Delta w I A C,(\operatorname{S} A C)$ & 0.56 & 1.79 \\
\hline Augustin et al., 2005, model \#5 & 13 & Cheese & $T, p H, A w,\left(N I T, P, C O_{2}\right)$ & 0.25 & 3.96 \\
\hline Augustin et al., 2005, model \#5 & 13 & $\begin{array}{l}\text { Liquid dairy } \\
\text { products }\end{array}$ & $T, p H, A w,\left(N I T, P, C O_{2}\right)$ & 0.88 & 1.13 \\
\hline Mejlholm and Dalgaard, 2009 & 13 & $\begin{array}{l}\text { Meat and fish } \\
\text { products }\end{array}$ & $\begin{array}{c}T, p H, A w, L A C, A A C, C A C, \\
(N I T, P, C O 2, S A C, D A C, B A C)\end{array}$ & 0.43 & 2.34 \\
\hline Model 1, two fitted parameters: & 6 & Fresh ricotta & $T$ & 1.10 & 1.11 \\
\hline Model 2, two fitted parameters: & 6 & Fresh ricotta & $T, p H$ & 1.06 & 1.09 \\
\hline $\begin{array}{l}\text { Recalibrated Mejlholm and Dalgaard, } \\
2009 \text { model; one fitted parameter }\end{array}$ & 6 & Fresh ricotta & $\begin{array}{c}T, p H, A w, L A C, A A C, C A C, \\
(N I T, P, C O 2, S A C, D A C, B A C)\end{array}$ & 0.78 & 1.31 \\
\hline
\end{tabular}

${ }^{\mathrm{a}} \mathrm{n}=$ Number of growth curves evaluated;

${ }^{\text {b }}$ T: temperature; Aw: water activity; $\mathrm{pH}$ : $\mathrm{pH}$ value; NIT: nitrite; $\mathrm{P}$ : phenol; $\mathrm{CO}_{2}$ : carbon dioxide; $\mathrm{NaCl}$ : natrium chloride; LAC: lactic acid; SAC: sorbic acid; AAC: acetic acid; CAC: citric acid; DAC: diacetate; BAC: benzoic acid; NaLac: sodium lactate; NaAcet: sodium acetate; KSorb: potassium sorbate; PLAC: potassium lactate.

Factors included in the specific models but not taken into account for ricotta are reported in brackets ( ). 
Table 7 Comparison of model performances by using the Acceptable Simulation Zone (ASZ) approach

57

\begin{tabular}{cccccc}
\hline & \multicolumn{3}{c}{$\begin{array}{c}\text { Percentages of measurements within a } \pm 0.5 \text { log CFU } \\
\mathrm{g}^{-1} \text { band along the simulated values }\end{array}$} \\
\hline $\begin{array}{c}\text { Product } \\
\text { brand code }\end{array}$ & $\begin{array}{c}\text { Temperature } \\
\left({ }^{\circ} \mathrm{C}\right)\end{array}$ & $\begin{array}{c}\text { Augustin et al. } \\
(2005), \\
\text { model \#5 } \\
\text { (liquid dairy) }\end{array}$ & Model 1 & Model 2 & $\begin{array}{c}\text { Recalibrated } \\
\text { Mejlholm and } \\
\text { Dalgaard (2009) } \\
\text { model }\end{array}$ \\
\hline A & 8.3 & 95 & 87 & 84 & 97 \\
A & 10.3 & 98 & 100 & 97 & 97 \\
A & 13.4 & 100 & 100 & 100 & 83 \\
A & 20.6 & 100 & 94 & 94 & 94 \\
A & $4-8$ & 77 & 83 & 83 & 29 \\
H & $4-8$ & 56 & 92 & 92 & 90 \\
A & $4-8$ & 29 & 65 & 81 & 48 \\
G & $12-16$ & 90 & 100 & 100 & 55 \\
G with added lactic acid & $12-16$ & 98 & 93 & 98 & 63 \\
G with added citric acid & 14.7 & 88 & 33 & 83 & 65 \\
\hline Mean ASZ score $(\%)$ & 14.7 & 88 & 92 & 96 & 91 \\
\hline
\end{tabular}

58 
59 Table 8 Predicted time to obtain a potential $2 \log$ CFU g ${ }^{-1}$ growth of L. monocytogenes in fresh ricotta.

60 Calculated as $\frac{2 \ln 10}{\mu_{\max }}$

\begin{tabular}{cccc}
\hline $\begin{array}{c}\text { Temperature } \\
\left({ }^{\circ} \mathrm{C}\right)\end{array}$ & $\mathrm{pH}$ & $\begin{array}{c}\text { Predicted time for } \\
\text { growth of 2 Log cfu g }\end{array}$ & $\begin{array}{c}\text { Augustin et al. } \\
(\mathrm{d})\end{array}$ \\
Model 2 & $\begin{array}{c}\text { Au05, model \#5) } \\
\text { liquid dairy }\end{array}$ \\
\hline 7 & 6.2 & 3.0 & 3.8 \\
6 & 6.2 & 3.6 & 4.8 \\
5 & 6.2 & 4.4 & 6.3 \\
4 & 6.2 & 5.6 & 8.7 \\
4 & 5.8 & 6.1 & 9.9 \\
5 & 5.9 & 4.7 & 6.9 \\
5 & 5.5 & 5.6 & 8.4 \\
4 & 5.6 & 6.7 & 52.9 \\
4 & 5.1 & 67.2 & 52.7 \\
\hline
\end{tabular}

61 
A

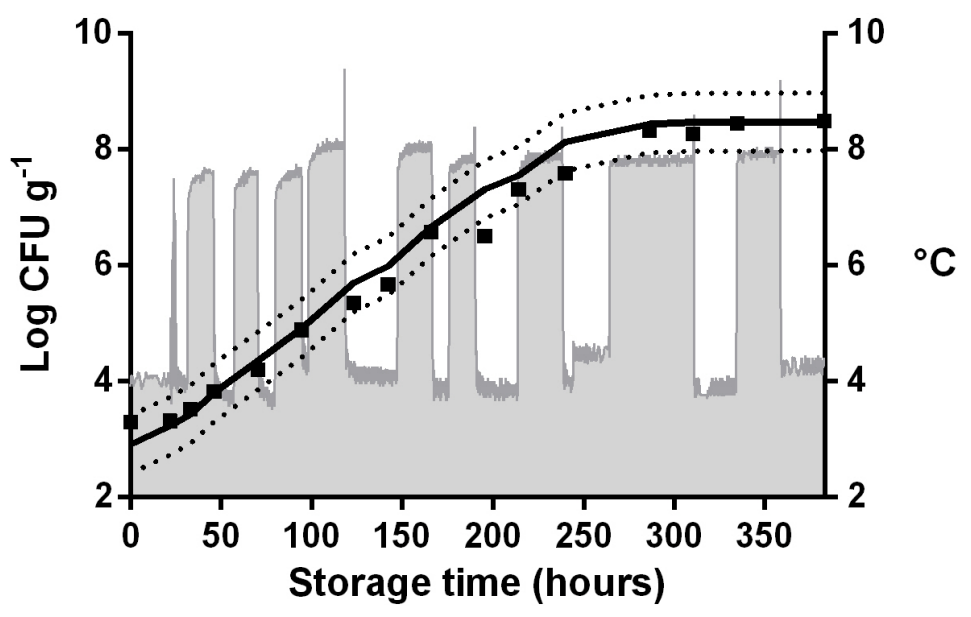

B

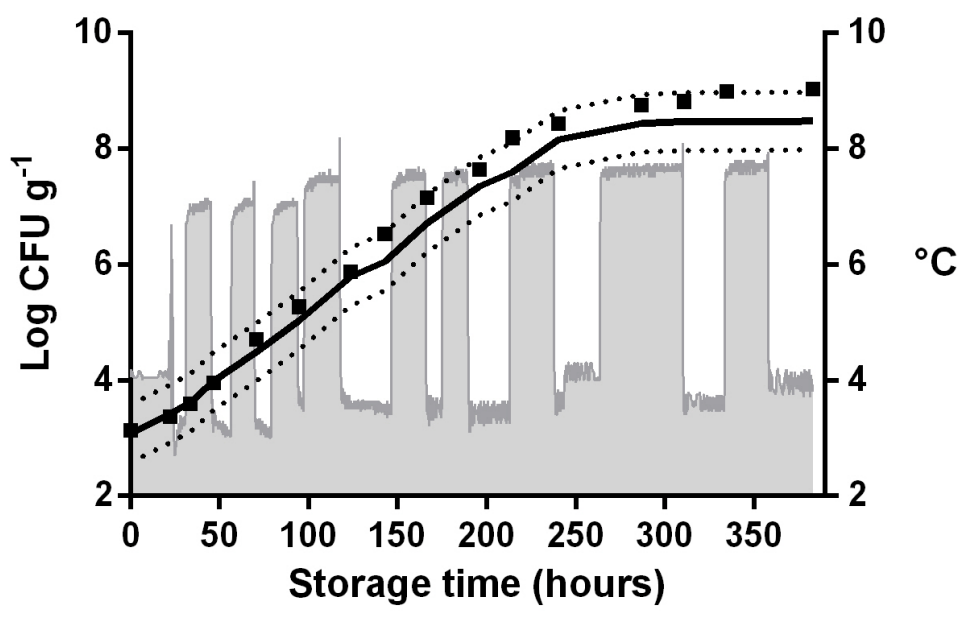

C

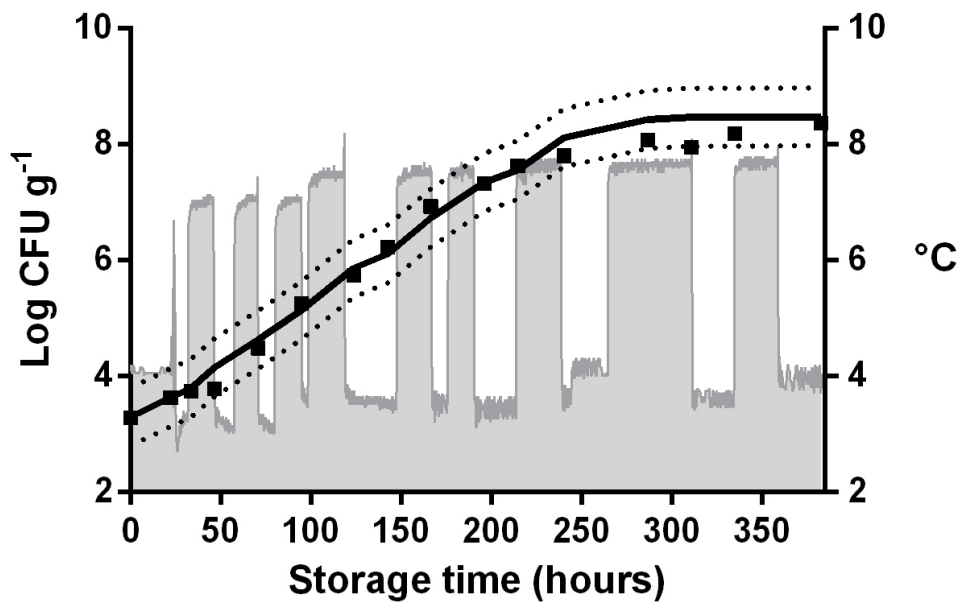




\section{Highlights}

- $\quad$ Eighteen challenge tests showed evident growth of Listeria monocytogenes in fresh ricotta

- A new product specific model predicted with good performance the growth of L. monocytogenes in ricotta $(\mathrm{Bf}=1.10)$

- $\quad$ Temperature and $\mathrm{pH}$ models facilitated product reformulation to prevent growth of L. monocytogenes in ricotta 